\title{
Promoting moderatism, countering radicalism: Religious discourse of high school students in Malang
}

\author{
Ahmad Arif Widianto*, Joan Hesti Gita Purwasih, Nanda Harda Pratama Meiji \& Rani Prita \\ Prabawangi \\ Universitas Negeri Malang, Malang City, Indonesia
}

\begin{abstract}
This article aims to map the religious discourse of high school (SMA) students in Malang. This mapping is important considering the strong contestation of religious ideology in educational institutions in recent years. The spread of radical ideology is massive and systematic, especially in students. This study explores the views of students and religious discourse circulating in the school environment with qualitative methods through in-depth interviews, observations and Focused Group Discussions (FGD) in 3 State Senior High Schools (SMAN). Students are aware of the infiltration of radicalism in schools through various modes and media. They are able to identify and classify religious views and discourses based on their respective rationalities and modalities. Although there are few students who agree with the vision and mission of radical understanding. However, in general, students with various religious identities counter radical ideology. Instead, they propagate religious moderation through actions and activities both intra- and extracurricular.
\end{abstract}

Keywords: Radicalism, Moderation, Religious Discourse of Students

\section{INTRODUCTION}

In recent years the discourse of ideology and religious behavior of students has strengthened in various countries (Woodward 2015). In Indonesia, the polemic of student religious discourse has led to discussions, studies and research (Arifianto 2019; Asrori 2016; Darraz 2013; Muchith 2016; Wijaya Mulya \& Aditomo 2019). The strengthening of the discourse is inseparable from the spread of radicalism and acts of terrorism that penetrate educational institutions (Arifianto 2019; Fatgehipon \& Bin-Tahir 2019; Wulansari \& Hidayat 2018; Muchith 2016). The strengthening of radicalism in Indonesia has resulted in the deteriorating image and credibility of Indonesia as a friendly and polite country in the eyes of the international world. On the contrary, Indonesia is described as a country whose people are blinded by fanaticism and brutalism (Fealy 2004) Religious radicalism is not a new phenomenon in Indonesia, but the impacts that result from it are very counterproductive and destructive to social-political stability in Indonesia (Purwasih \& Widianto 2020; Robingatun 2017).

Religious radicalism can be traced in historic tragedies through terrorist events that have harmed humanity in Indonesia. Although, radicalism does not always manifest in physical violence, radicalism can be transformed into terrorism (Ismail \& Bonar 2012). Infiltration of religious radicalism in students becomes an emergency warning to immediately make prevention, treatment and recovery through a series of action interventions. One such effort is through the mapping of religious discourse in high school. During this time, radicalism can easily spread to schools because of the lack of understanding and awareness of the school related to the potential, form and patterns of infiltration so as to weaken the school's resilience system (Purwasih \& Widianto 2020).

*Corresponding author: ahmad.arif.fis@um.ac.id 
This article seeks to map the religious discourse of high school students in Malang, especially in 3 senior high schools. Historically, radical movements and terrorism have been linked to the Malang region which began in 1993 through the promotion of Hizb ut-Tahrir Indonesia in Brawijaya University and Malang State University (Yumitro et al. 2018). In the last few years in Malang it has been uncovered in the hideout of persons identified as terrorists. Such reality reinforces the indication of the spread of radicalism that threatens students in Malang. The purpose of this article is to give an overview of student religious discourse in the midst of the infiltration of radical understanding in senior high schools through various modes and media (Darraz 2013; Muchith 2016).

\section{LITERATURE REVIEW}

Strengthening radicalism according to Porta and Free is characterized by two things (Pranawati 2018). First, there is the strengthening of religious movements and ideologies that have scheduled social and political changes. Second is the strengthened pro-violence attitudes and actions in response to conflict and political contestation. One of the demands of the radical movement is to establish an Islamic State. In another version it is stated that the Islamic radical movement is limited to wanting the implementation of Islamic shari'ah (Jakarta charter). The demand means negating the legitimate state ideology, namely Pancasila. In fact, Pancasila itself according to the founders of the nation is sourced from religious principles and cultural moral values that are contextual and relevant to the socio-cultural style of Indonesian society (Beck \& Irawan 2016; van Bruinessen 2002). The decline in the function of the Pancasila as an ideology according to Heywood can weaken state control over the socio-political practices of the community (Pranawati 2018).

The rise of radicalism in Indonesia is growing rapidly due to political pressure from the government regime and recolonization from the United States (Jati 2017). For young people, especially Muslims, radicalism is getting stronger because of (1) the phase of political transition (2) the transformation of the Islamic radical movement and (3) the high unemployment (Azca 2013). In this case, young people affected by religious radicalism are characterized as; (1) intolerant of differences; (2) finding it easy to radicalize other parties; (3) rigidly obedient to the leader; (4) trying to control campus political space (5) supporting violence by radicals; (6) being against the government which is considered secular and deviates from religion (Yusar 2016).

Religious moderation is the key to fighting radicalism and extremism (Ma'arif 2019; Suharto 2019) and at the same time is a way to care for harmony between religious communities (Kawagung 2019). A measure of moderation can be determined through the following indicators ("Buku Moderasi Beragama," n.d.). In line with these indicators, individual religious behavior that reflects moderation can be seen from the dimensions: (1) ideological (2) ritual (3) mystical (4) intellectual and (5) social (Fauzi 2007: 66-68). In the Indonesian context, Moderation is rooted in noble values and national consensus as set out in the 1945 Constitution, Pancasila and the motto of "Unity in Diversity." Thus, religious moderation is in line with the spirit of nationalism which upholds unity and mutual cooperation.

\section{RESEARCH METHODOLOGY}

This study uses qualitative methods in order to explore data and attain a deep understanding of social phenomena (Silverman 2013). This method emphasizes deeper description (thick description) which is one element of phenomenological research that looks at phenomena from the point of view of social actors and understanding of social processes rather than aspects of social statistics (Blaikie 2010). In qualitative research, the logic used is abstractive inductive, namely the flow of thinking from the specific to the general, namely conceptualization, categorization and description based on field data. The characteristics and procedures of qualitative research are very relevant 
to the design of this study, which is to map the model the structure of social cohesion in a multireligious society. Of course, to be able to do this requires deep data mining and an understanding of social processes. This research was conducted on 200 students of 3 high schools in Malang through in-depth interviews, participatory observation and focus group discussion. Schools are chosen based on the level of heterogeneity of student composition in religion.

\section{FINDING DAN DISCUSSION}

Religious radicalism is pervasive among young Muslim students. Students are not only victims of religious radicalism but also as pioneers and agents of the dissemination of their teachings (van Bruinessen 2002). In the perspective of youth studies, students are subjects who are vulnerable to radicalism because they are still in the stage of transition and the search for identity. Young people are still unstable and do not yet have a mature personality, as well as an understanding of the outside world. In this unstable condition, young people experience a dilemma in the search for identity (Pranawati 2018). The flow of information and knowledge is taken for granted without careful thought (Azca 2013). The vulnerability and lack of understanding of young people facilitates the infiltration of notions that are contrary to the beliefs and ideology of the state.

Surprisingly, radicalism is now developing rapidly through various levels of educational institutions not only on campus but also in schools (Wulansari \& Hidayat 2018; Prijanto et al. 2019). Even though the school is an institution that can shape the mindset and character of students. This is certainly a real threat to the life of the nation and state in the future. Various survey reports show that in the last 5 years radicalism has developed among high school students (adminppimuinjakarta n.d.). This is certainly very counterproductive to the survival and stability of the nation and state. Students who are supposed to be the next generation actually destroy the nobility of social cultural values in Indonesia. Schools as educational institutions and intellectual producers are not able to give birth to the nation's successors as expected. Radical groups in the future have the potential to transform into a terrorism movement, although not as a whole (Ismail \& Bonar 2012).

The development of radicalism spread through various formal and informal public spaces and arenas (Azca 2013; Muchith 2016; Pranawati 2018). The entry of radical understanding into the school environment can come from the School Student Organization (Abdallah 2016; Darraz 2013; Yusar 2016), textbooks and LKS Radical Islamic subject matter, religious extracurricular activities, radical thinking teachers and school alumni who are radical incorporated in radical groups (Maulana 2017), until the education curriculum is radical. As a result of the inclusion of radical ideas, social life in schools becomes intolerant, exclusive, anti-diversity and colored by violence.

In this context, the results of previous research in high schools in Malang also show the growth of the seeds of radical thought (Purwasih \& Widianto 2020). Although the percentage can still be tolerated, the stretching of its development and distribution is very worrying. For example, $24 \%$ of students in Malang stated that they strongly agreed with the statement "violence is sometimes needed to enforce religious rules." Meanwhile, the students that agree are $49 \%$ of the total. The hesitant answer is $26 \%, 1 \%$ disagrees, and $0 \%$ strongly disagrees ( 1 respondent). This number is only from one variable, not the whole. But interestingly, in the process of infiltration and recruitment of members of radical groups in SMA Malang there was a turmoil among students. Some informants stated that they had been targeted and ended up being members of radical groups even though they were not official (bai'at). However, in its development, they tried to go out and break relations with the group. According to the informant, radical teachings can cause followers to commit terrorism. Because radical teachings are deviant teachings in order to achieve a goal, but if the goal is not achieved then they will use violent methods such as terror in the name of a particular religion.

Radical teachings according to informants want to make changes in the social and political fields but use violent methods, such as wanting to replace the state ideology, namely Pancasila, with an ideology based on Islamic law. Because their desire was not heeded, they finally carried out terror everywhere, such as suicide bombings in Surabaya and Pasuruan some time ago in the name of 
jihad. Radicals have a political orientation not only to seize state power, but also carry the spirit of revivalism and religious understanding to respond to global conditions that are considered far from the ideal values of Islam.

In this research, Some informants consider the teachings of radicalism to teach jihad by violence according to the informant's remarks as walking in the path of Allah. But the informant in this research also stated that jihad at this time did not have to be by force but rather by competing in the field of knowledge. According to the informant, tolerance in religious life is important because we are Indonesian, even though we are different but still one. Even though they have different religious beliefs, they must help each other, as well as the two extracurriculars, namely SKI and BCF. Religious harmony can be seen from the help that is done by each organization, this is explained by the informant that if SKI or BCF will do an activity then they will help each other in funding. The fundraising they do is called shoping or in Islam is a kind of fundraising through a charity box during Friday prayers. The funds collected will be shared equally between SKI and $\mathrm{BCF}$, the rest will be used for social services carried out by these two organizations. Forms of interfaith tolerance other than those described above are participation in inter-extra activities, for example SKI members hold activities in schools, BCF members also attend these activities, but when the activity takes place they perform their own worship based on their beliefs in a room or place provided.

\section{CONCLUSION AND FURTHER RESEARCH}

This research shows that high schools are also being targeted by the infiltration of radical ideas through various processes and media by exploiting the weaknesses of the schools' resilience systems. Students become victims as well as agents of the spread of radicalism from radical groups through various recruitment methods. Although some informants agreed with the goals set by radical groups, on the other hand the majority of students rejected the infiltration of radicalism in schools because they were considered not in accordance with teachings and beliefs. On the contrary, the students actually promote tolerance and moderation in religion through both intra and extra-curricular activities and activities such as celebrating collective and collaborative religious days, interfaith competitions, and scout activities. This reality shows that although students are susceptible to radicalism, in reality they are able to choose ideologies that are believed to be rational, moral and faith based.

\section{REFERENCES}

I., Wulansari, D. and Hidayat, N. (2018) 'Radicalism in indonesia and the reflective alternatives to reduce', People: International Journal of Social Sciences. doi: 10.20319/pijss.2018.33.15541564.

Abdallah (2016) 'Exclusivism and radicalism in schools: State policy and educational politics revisited', Studia Islamika. doi: 10.15408/sdi.v23i3.4425.

Arifianto, A. R. (2019) 'Islamic Campus Preaching Organizations in Indonesia: Promoters of Moderation or Radicalism?', Asian Security. doi: 10.1080/14799855.2018.1461086.

Asrori, A. (2016) 'Contemporary religious education model on the challenge of indonesian multiculturalism', Journal of Indonesian Islam. doi: 10.15642/JIIS.2016.10.2.261-284.

Azca, M. N. (2013) 'Yang muda, yang radikal: Refleksi sosiologis terhadap fenomena radikalisme kaum muda muslim di Indonesia pasca orde baru', Maarif.

Beck, D. M. C. and Irawan, I. (2016) 'Islam, pancasila and value systems of indonesian national education', Jurnal Pendidikan Islam. doi: 10.15575/jpi.v1i1.610.

Blaikie, N. (2010) 'Designing Social Research', in. van Bruinessen, M. (2002) 'Genealogies of Islamic radicalism in post-Suharto Indonesia', South East Asia Research. doi: 10.5367/000000002101297035.

Darraz, M. A. (2013) 'Radikalisme dan lemahnya peran pendidikan kewargaan', Dalam Menghalau Radikalisasi Kaum Muda: Gagasan Dan Aksi. Jakarta: Jurnal Institut Maarif, 8, pp. 154-173. 
Fatgehipon, A. H. and Bin-Tahir, S. Z. (2019) 'Building students state defending awareness in preventing the radicalism', International Journal of Scientific and Technology Research.

Fealy, G. (2004) 'Islamic radicalism in Indonesia: The faltering revival?', Southeast Asian Affairs, 2004(1), pp. 104-121.

Ismail, H. and Bonar, T. N. (2012) 'Dari Radikalisme Menuju Terorisme, Studi Relasi dan Transformasi Organisasi Islam Radikal di Jawa Tengah dan DI Yogyakarta', Jakarta: Pustaka Media.

Jati, W. R. (2017) 'Radikalisme politik kelas menengah muslim indonesia pasca reformasi', MIQOT: Jurnal Ilmu-ilmu Keislaman. doi: 10.30821/miqot.v41i1.309.

Ma'arif, S. (2019) 'Reinventing pesantren's moderation culture to build a democratic society in the post-reform Republic of Indonesia', Pertanika Journal of Social Sciences and Humanities.

Maulana, D. (2017) 'The exclusivism of religion teachers: Intolerance and radicalism in Indonesian public schools', Studia Islamika. doi: 10.15408/sdi.v24i2.5707.

Muchith, M. S. (2016) 'Radikalisme dalam dunia pendidikan', ADDIN. doi: 10.21043/addin.v10i1.1133.

Pranawati, H. L.; W. S.; C. S. B.; I. A.; M. N.; R. (2018) Kaum Muda Muslim Milenial: Konservatisme, Hibridasi Identitas, Dan Tantangan Radikalisme.

Prijanto, J. H., Padang, A. T. and Susanti, A. E. (2019) 'Indication of the Effect of Radicalism on Christian High School Students, Lippo Karawaci', in. doi: 10.2991/icskse-18.2019.4.

Purwasih, J. H. G. and Widianto, A. A. (2020) School Resilience And Religious Radicalism In Senior High Schools, In: Emerging Trends In Psychology, Law, Communication Studies, Culture, Religion, And Literature In The Global Digital Revolution. 1st Editio.

Robingatun, R. (2017) ‘Radikalisme islam dan ancaman kebangsaan’, EMPIRISMA. doi: 10.30762/empirisma. v26i1.684.

Silverman, D. (2013) Doing qualitative research: A practical handbook. Sage.

Suharto, T. (2019) 'Examining Moderate Understanding of Islam among Islamic Higher Education Students of State Islamic Institute Surakarta', TEOSOFI: Jurnal Tasawuf dan Pemikiran Islam.

Wijaya Mulya, T. and Aditomo, A. (2019) 'Researching religious tolerance education using discourse analysis: a case study from Indonesia', British Journal of Religious Education. doi: 10.1080/01416200.2018.1556602.

Woodward, K. (2015) 'Indonesian Schools: Shaping the Future of Islam and Democracy in a Democratic Muslim Country.', Journal of International Education and Leadership.

Yumitro, G., Kurniawati, D. and Saiman, S. (2018) 'Terrorism Issues and the Development of Transnational Islamic Movements in The Region of Malang'.

Yusar, Y. (2016) 'The Youth, The Sciences Students, and Religious Radicalism', Al-Ulum. doi: 10.30603/au.v16i2.154. 